\title{
Potential analysis of small and medium industries (SMIs) in Lima Puluh Kota Regency, West Sumatra
}

\author{
Elfi Khairina*; Adrimas; Sjafrizal \\ Faculty of Economics, Universitas Andalas, Indonesia \\ *To whom correspondence should be addressed.Email: khairinaelfi@ gmail.com
}

\begin{abstract}
Small and Medium Industries (SMIs) play an important role in the industrial sector of the Lima Puluh Kota Regency, even though the growth rate has fluctuated in the last six years. The purpose of this study is to identify the potential of Small and Medium Industries (SMIs) Lima Puluh Kota Regency that have comparative and competitive advantages. The analytical methods are location quotient (LQ) and shift-share analysis. Using a variable value of industrial production based on Indonesian Standard Business Classification in five digits of industrial commodity was found, the basic organic chemical industry for raw materials for dyes and pigments, embroidery industry, wood container industry, garment industry of leather, industrial stone goods for home use stairs and displays, the gypsum industry, the components and equipment industry of two- and three-wheeled motorcycles, the soft drink industry and the coconut oil industry are industries that have a comparative as well as a competitive advantage. These industries are suggested to be lead industries in the development of Small and Medium Industries (SMIs) in Lima Puluh Kota Regency.
\end{abstract}

Keywords: Small and medium industries (SMIs), Location quotient (LQ), Shift-share analysis, Comparative advantage, Competitive advantage

JEL Classification: L25, L52

\section{INTRODUCTION}

In the economic development, the industrial sector is the leading sector that will encourage other sectors to develop. Various literature and empirical studies have proven this issue. The industrial sector processes natural resources into products that have higher added value. So that, with the advancement of the industrial sector, the total value added produced will be greater and have an impact on increasing regional economic growth. The development of the industrial sector will increase employment, reduce poverty and increase gross regional domestic product.

In 2011-2016, the economic growth rate of Lima Puluh Kota Regency on average slowed $-0.17 \%$. The lowest growth rate in 2015 was $5.56 \%$ (Figure 1). One effort that can be made to increase the acceleration of economic growth is by strengthening the industrial sector. According to Adrimas (2008), industrial development needed to support the acceleration of regional economic development is based on local resources and labor intensive. Furthermore, Permana, Marimin, \& Suprayitno (2015) explained that in regions in developing countries, SMIs were the main driver of economic growth. 
According to the industry grouping by the Indonesian Ministry of Industry, the industrial sector of Kabupaten Lima Puluh Kota belongs to the Small and Medium Industries group. In Figure 1, it is known that the growth rate of the industrial sector has fluctuated in the last six years. The average growth of the 2011-2016 industry is 5.15\%, below the sectoral growth average of $5.96 \%$. In terms of sectoral contribution, the industrial sector tends to decline with the average decline in 2011-2016 being $-0.13 \%$ (Gross Regional Domestic Product based on constant price of 2010). The tendency to decrease the contribution of the industrial sector has occurred since 2002. This indicates a decline in the performance of the industrial sector (SMIs).

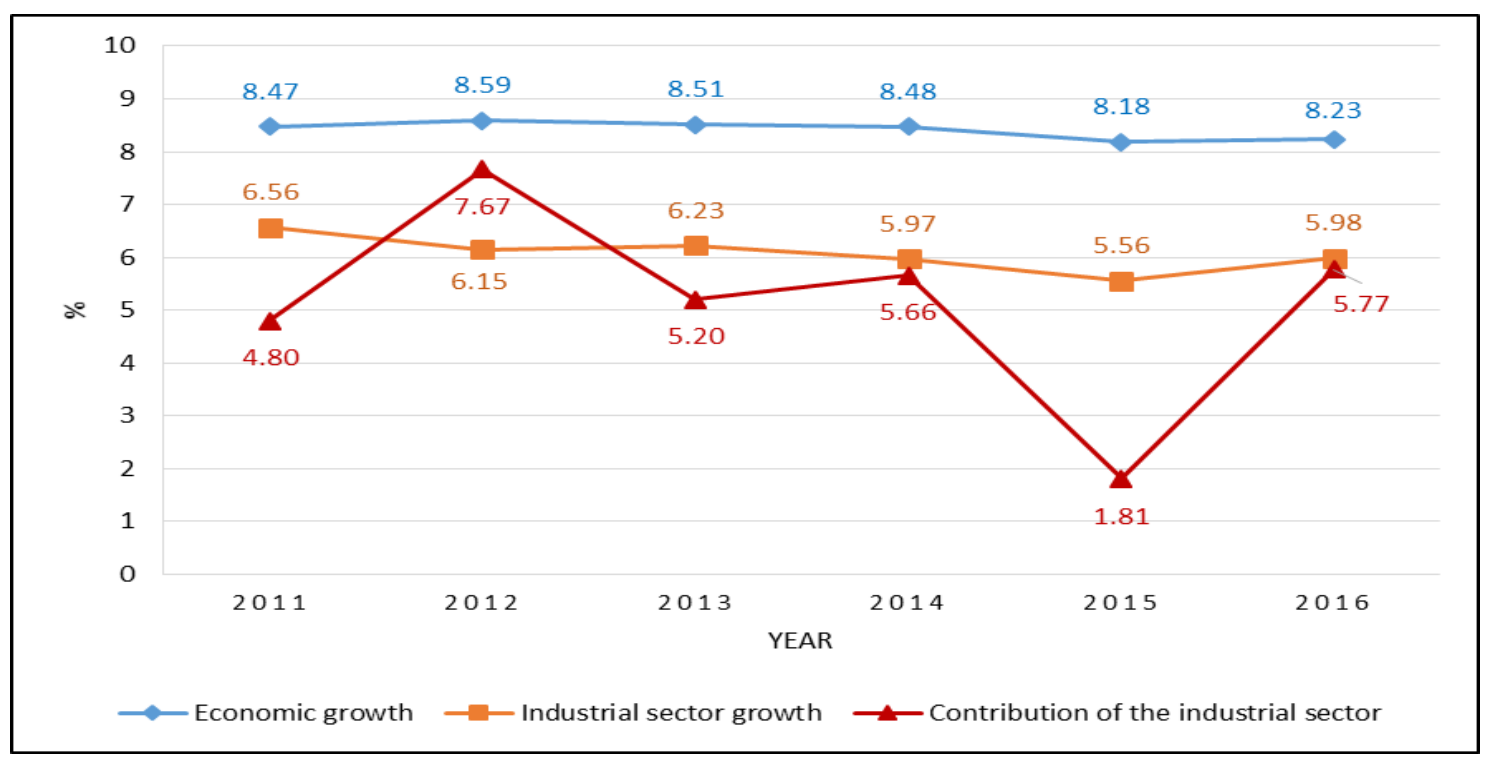

Figure 1. Economic growth rate, industrial sector and contribution of the industrial sector, Lima Puluh Kota Regency in 2011-2016

Source: Central Bureau of Statistics, Limapuluh Kota Regency, 2016-2017

Based on these problems, an analysis is needed to determine the potential of SMIs in Lima Puluh Kota Regency. Then, as a guideline in the development of the industrial sector based on Legislation Number 3/2014 concerning Industry. According to this legislation, the Regional Government needs to determine the leading industry in the region so that the development of the industrial sector is directed, consistent and can encourage economic growth. The direction of industrial development is outlined in the district/city industrial development plan. This plan is prepared by referring to the national industrial development master plan and national industrial policy. Furthermore, it must be based on the potential of regional industrial resources, provincial spatial plans, regional spatial plans, harmonious balance with socio-economic activities and environmental carrying capacity. So that, the purpose of this study is to identify small and medium industries (SMIs) that have comparative and competitive advantages that will be leading industries in Lima Puluh Kota Regency.

Sunaryanto (2006) in Permana, Marimin, \& Suprayitno (2015), stated that the characteristics of SMIs are their ability to survive and easily enter the market and are easily out of the market (easy market entry and out of market). SMIs has a higher resistance when compared to large scale industries. The intended resilience is the ability of the SMIs to adapt to market conditions and unfavorable economic conditions. SMIs 
is intensive labor, has a small scale of business and investment value, and utilizes local resources with simple processing techniques.

Government policy for empowerment of SMIs is outlined in Law Number 3/2014 section 72. The objectives to be achieved from SMIs are: (1) competitive of SMIs; (2) significant role in strengthening the structure of the national industry; (3) alleviating poverty through expanding employment opportunities; and (4) produce industrial goods and/ or services for export. In section 73 , it is explained that in formulating the SMIs development policy, at least it refers to: regional industrial resources (local resources), strengthening and deepening the structure of the national industry and the development of national and global industries. Efficient utilization of local industry resources will enhance the comparative and competitive advantages of SMIs. So that SMIs developed into a highly competitive industry. Therefore, the formulation of appropriate policies for leading SMIs, strengthening institutional capacity and providing facilities are the strategies needed for the development of SMIs.

Tarigan, (2009) explained that comparative advantage was first put forward by David Ricardo (1917) in the theory of trade between countries (international). This theory was then applied to the regional economy. An area is said to have a comparative advantage if the role of a sector/commodity is greater than the role of the reference sector/commodity area. This means that these advantages are relative to the reference area. According to this theory the economy of a region is divided into two (2) main sector groups, namely the Base Sector (B) and the Non-Base Sector (S). The Base Sector is a sector that is the backbone of the regional economy because it has a relatively high comparative advantage. While the Non-Base Sector is other sectors which are less potential but function as supporting the Base Sector or Service Industries.

Douglas C. North (1956) in Sjafrizal (2014) explains that economic growth is determined by the amount of competitive advantage possessed by a region. If a region can encourage the growth of sectors that have competitive advantages as a basis for export activities, then the economic growth of the region concerned will increase rapidly. This theory is known as economic base theory. Competitive advantage according to Tarigan (2009) analyzes the ability of a region to market its products outside the region/overseas/global market. The difference with comparative advantage is that we do not compare the potential of the same commodity in one area with another. However, we compare the potential of a region's commodities to all other regional commodities in the global market.

Previous research related to this research was carried out by Pinem (2016). The research conducted a study in Binjai City to find a strategy for developing industrial estates through analysis of the leading sectors of Binjai City. This study uses the LQ method, Shift Share and SWOT to find the right industry to be developed in the City of Binjai according to its regional potential, then see its suitability with the Binjai City's Regional Spatial Plan about industrial sector development areas. From the research it was found that the potential sectors to be developed in Binjai City were the construction, finance and services sectors. So that the industrial policy directives that are set are not in accordance with the potential of the region.

The research conducted by Pradigda (2016) with the title "Strategic Planning for Regional Development Based on Regional Products, Study on the Office of Industry and Trade at Blitar Regency". This study aims to determine the priority superior products of Blitar Regency and its development strategies. In determining superior products through two stages, namely identification of superior processing sub-sectors 
through shift share analysis, then identified superior products are based on the leading industry sub sector. The Analytical Hierarchy Process (AHP) method is used to determine priority superior products. The results of the study found that coconut shell craft as a superior product of Blitar Regency with its development strategy based on the SWOT matrix was an S-O strategy.

Research by Irmawati (2015) on Analysis of Leading Industries in Central Java Province by using processing industry data for 2007-2012. The purpose of this study was to identify the types of industries that are leading industries in Central Java Province. The analytical tools used are LQ analysis (Static LQ and Dynamic LQ) and Shift Share. The results showed that industries that were the leading industries in Central Java Province included the beverage industry, tobacco processing industry, textile industry, apparel industry, wood industry, printing industry, furniture industry, and other manufactur industries.

Bao-jin, Xing-peng, \& Li-na (2010) research, entitled Industrial Structure Evolution and Economic Growth in Dingxi City Based on Shift-share Method and Location Quotient Analysis, used statistical data from 2004-2008. Shift-share and LQ Analysis are used to compare the economic development of regions in Dingxi City in 2004 and 2008. This study analyzes the advantages and disadvantages of industrial structure, competitiveness and the impact of existing industrial structures on economic growth. The finding is that industrial development focuses on primary, secondary and tertiary industries. The efforts put forward to accelerate the economic development of regions in Dingxi City, among others, increase input in the characteristics of agriculture, encourage the development of primary industries, accelerate the development of large and medium-sized industrial companies, enhance secondary industrial development, strengthen environmental improvements comprehensively in tourist areas, and actively developing tertiary industries.

\section{METHODS}

To identify SMIs which have comparative and competitive advantages in Lima Puluh Kota Regency by using LQ and shift share analysis. The variables that can be used are labor, value added, population, land area, production value, and regional income (Tan, 2010). In this study we use the production value variable of SMIs Lima Puluh Kota regency and West Sumatra Provinces in 2011-2016 based on the grouping of Indonesian Standard Business Classifications 2009. The industrial grouping data used is Indonesian Standard Business Classifications two digits and five digits of industrial, so that we can obtain leading SMIs at the level of the main groups and groups (commodities). The data used is secondary data obtained from the Department of Industry and Labor, Lima Puluh Kota Regency and the Office of Industry and Trade of West Sumatra Province.

Indonesian Standard Business Classifications 2009 is an Indonesian business field grouping adopted by the Central Statistics Bureau (BPS) based on International Standard Classification (ISIC Rev.4). The manufacturing industry in Indonesian Standard Business Classifications is included in category C. While the industrial grouping code based on Indonesian Standard Business Classifications 2009 is two digits can be seen in Table 3. The industrial data used is Indonesian Standard Business Classifications industry grouping two and five digits. From this analysis, the leading industries will be obtained according to the main groups and groups (commodities). 
Table 1. Type of industry based on two digits Indonesian Standard Business Classifications 2009

\begin{tabular}{|c|c|c|c|}
\hline Code & Industry & Code & Industry \\
\hline 10 & Foods & 22 & Rubber, Rubber Products and Plastic Items \\
\hline 11 & Drinks & 23 & Non-Metallic Mining Goods \\
\hline 12 & Tobacco Manufacturing & 24 & Base metal \\
\hline 13 & Textile & 25 & Metal Goods Not Machines and Equipment \\
\hline 14 & Garment & 26 & Computers, Electronics and Optics \\
\hline 15 & Leather, Leather Goods and Footwear & 27 & Electrical equipment \\
\hline 16 & $\begin{array}{l}\text { Wood, Wood Products (excluding } \\
\text { furniture) and Cork, Woven Goods } \\
\text { from Bamboo, Rattan and the like. }\end{array}$ & 28 & Machinery and Equipment \\
\hline 17 & Paper and Paper Products & 29 & $\begin{array}{l}\text { Motorized Vehicles, Trailers and Semi } \\
\text { Trailers }\end{array}$ \\
\hline 18 & $\begin{array}{l}\text { Printing and Reproduction of } \\
\text { Recording Media }\end{array}$ & 30 & Other Transport Equipment \\
\hline 19 & Coal and Petroleum & 31 & Furniture \\
\hline 20 & Chemicals and items from chemicals & 32 & Other Manufacturing \\
\hline 21 & $\begin{array}{l}\text { Pharmacy, Chemical and Traditional } \\
\text { Medicine Products }\end{array}$ & 33 & Machine Repair and Installation Services \\
\hline
\end{tabular}

Analysis of location quotient (LQ) is a method that compares the role of a sector in an area with the role of the sector at a broader level. In this case the area of the Lima Puluh Kota Regency and the Province of West Sumatra as a reference area. So that there will be an SMIs groups and commodities that has a comparative advantage relative to other regions (Sjafrizal, 2014). According to Tan (2010), the limitations of the LQ method are simple calculation techniques so that accurate data is needed to avoid seasonal and annual bias. For this reason, LQ analysis needs to be done in a time series so that the average LQ value is obtained. In this study, LQ analysis was conducted in time series for the SMIs in 2011-2016.

LQ values can be measured using the following formula:

$$
L Q_{i j}=\frac{y_{i j} / \sum_{i} y_{i j}}{\sum_{j} Y_{i j} / \sum_{i} \sum_{j} Y_{i j}}
$$

Where:

$\mathrm{LQ}_{\mathrm{ij}} \quad$ : Industrial LQ value in Lima Puluh Kota Regency

$\mathrm{y}_{\mathrm{ij}} \quad$ : production value of industry i, Lima Puluh Kota Regency

$\sum_{\mathrm{i}} \mathrm{y}_{\mathrm{ij}} \quad$ : Total production value of industry i, Lima Puluh Kota Regency.

$\sum_{\mathrm{j}} \mathrm{Y}_{\mathrm{ij}} \quad$ : production value of industry $\mathrm{i}$, West Sumatra Province

$\sum_{\mathrm{i}} \sum_{\mathrm{j}} \mathrm{Y}_{\mathrm{ij}}$ : Total production value of industry $\mathrm{i}$, Province of West Sumatra

Provisions in the assessment of comparative advantage of LQ values are, if the value of $L Q>1$ means that the portion of industrial production value in Lima Puluh Kota District to total industrial production in Lima Puluh Kota Regency is greater than the portion of production value for the same type of industry for the area of West Sumatra Province. This indicates that industry $i$ is a base or industrial industry that has a comparative advantage (superior area). Whereas if LQ $<1$ means industry $i$ is non-base or not a regional superior industry. 
To measure the magnitude of competitive advantage, the shift-share analysis method is explained by Blair (1991) in Sjafrizal (2016) with the following formulations:

$$
\begin{aligned}
\Delta \mathrm{y}_{\mathrm{i}} & =\left[\mathrm{y}_{\mathrm{i}}\left(\mathrm{Y}^{\mathrm{t}} / \mathrm{Y}^{\mathrm{o}}-1\right)\right]+\left[\mathrm{y}_{\mathrm{i}}\left(\mathrm{Y}_{\mathrm{i}}^{\mathrm{t}} / \mathrm{Y}_{\mathrm{i}}^{\mathrm{o}}\right)-\left(\mathrm{Y}^{\mathrm{t}} / \mathrm{Y}^{\mathrm{o}}\right)\right]+\left[\mathrm{y}_{\mathrm{i}}\left(\mathrm{y}_{\mathrm{i}}^{\mathrm{t}} / \mathrm{y}_{\mathrm{i}}^{\mathrm{o}}\right)-\left(\mathrm{Y}_{\mathrm{i}}^{\mathrm{t}} / \mathrm{Y}_{\mathrm{i}}^{\mathrm{o}}\right)\right] \\
\Delta y_{i} & =R S_{i}+P S_{i}+D S_{i}
\end{aligned}
$$

Where:

$\Delta y_{i} \quad: \quad$ Increase in value added sector $\mathrm{i}$

$\mathrm{y}_{\mathrm{i}}{ }^{\mathrm{o}} \quad$ : Sector value added at the regional level at the beginning of the period

$\mathrm{y}_{\mathrm{i}}^{\mathrm{t}} \quad$ : Value added of sector $\mathrm{i}$ at the regional level at the end of the period

$\mathrm{Y}_{\mathrm{i}}{ }^{\mathrm{O}} \quad$ : Value added sector $\mathrm{i}$ at the national level at the beginning of the period

$\mathrm{Y}_{\mathrm{i}}^{\mathrm{t}} \quad$ : Value added sector $\mathrm{i}$ at the national level at the end of the period

The equation above shows that an increase in production or value added of a sector at the regional level can be decomposed on 3 parts:

1. Regional Share $(R S)$ : $\left[\mathrm{y}_{\mathrm{i}}\left(\mathrm{Y}^{\mathrm{t}} / \mathrm{Y}^{\mathrm{o}}-1\right)\right]$ is a component of regional economic growth caused by external factors, namely: increasing regional economic activities due to national policies that apply to all regions.

2. Proportionality Shift (PS/ Mixed Shift): $\left[\mathrm{y}_{\mathrm{i}}\left(\mathrm{Y}_{\mathrm{i}}^{\mathrm{t}} / \mathrm{Y}_{\mathrm{i}}{ }^{\mathrm{o}}\right)-\left(\mathrm{Y}^{\mathrm{t}} / \mathrm{Y}^{\mathrm{o}}\right)\right]$ is a component of regional economic growth caused by a good regional economic structure, which specializes in fast-growing sectors such as the industrial sector.

3. Differential Shift (DS/ Competitive Shift): $\left[\mathrm{y}_{\mathrm{i}}\left(\mathrm{y}_{\mathrm{i}} / \mathrm{y}_{\mathrm{i}}{ }^{\mathrm{o}}\right)-\left(\mathrm{Y}_{\mathrm{i}}^{\mathrm{t}} / \mathrm{Y}_{\mathrm{i}}{ }^{\mathrm{o}}\right)\right]$ is a component of regional economic growth due to competitive regional specific conditions. This element of growth is a regional competitive advantage that can drive the export growth of the region concerned.

The differential shift (DS) component in the shift share equation is the value used to determine the competitive advantage of the SMIs. Provisions in evaluating competitive advantage is if DS is positive, it is said that this SMIs is an industry that has a competitive advantage/competitiveness. If it is negative, it is said that this type of industry does not have competitive advantage. The negative differential shift, explains that industrial growth at the regional level is lower than the industrial growth at the national level.

\section{RESULTS AND DISCUSSION}

The results of the analysis with the Location Quotient (LQ) method on SMIs Lima Puluh Kota Regency using two digits Indonesian Standard Business Classifications are presented in Table 2. SMIs are spread across 20 industries in Lima Puluh Kota Regency. There are four industrial groups that have not grown, namely: (1) leather industry, leather goods and footwear; (2) pharmaceutical industries, chemical and traditional medicinal products; (3) basic metal industry, and (4) electrical equipment industry.

The results of the analysis show that the tobacco processing industry has the highest average LQ value, followed by the paper and paper products industry. Other industries that have a large LQ value of 1 in sequence are: (1) the food industry, (2) the motor vehicle industry, trailers and semi trailers, (3) the textile industry, (4) the wood industry, wood products and cork (excluding furniture), woven goods from bamboo, rattan and the like, (5) non-metal excavation industry, (6) industrial chemicals and goods from chemicals. Overall there are 8 types of industries with a large average LQ value of 1 . This industry is considered to have a comparative advantage compared to 
other industries. This means that the role of this industry in Lima Puluh Kota Regency are relatively larger than the same industry in West Sumatra Province. Factors that make these industries have comparative advantages, among others, are due to the natural conditions of the Lima Puluh Kota Regency, examples: industrial chemicals and goods from chemicals. Factors that make these industries have comparative advantages, among others, are due to the natural conditions of the Lima Puluh Kota Regency. Examples of chemicals. In addition, the textile industry and other handicraft industries are due to the special skills that the community has for generations.

While the other 12 industries with an average $L Q<1$, are interpreted as not having comparative advantages, namely: (1) drinks, (2) apparel, (3) printing and reproduction of recording media, (4) coal and petroleum, (5) rubber, articles of rubber and plastic, (6) metal goods not machinery and equipment, (7) machinery and equipment (8) other processing (9) computers, electronics and optics (10) other means of transportation (11) furniture, (12) machine-equipment repair and installation services. In 2015, the coal and petroleum industry had a LQ value of 1.55 , but this industry only developed in 2015 so that the average LQ value was small than 1 . The machinery and equipment industry in 2011-2013 also had LQ values> 1, but 2014-2016 has decreased so that the average LQ $<1$. This indicates that these industries still have the potential to have a comparative advantage in the future.

Table 2. LQ analysis result of SMIs 2011-2016

\begin{tabular}{|c|c|c|c|c|c|c|c|c|}
\hline \multirow{2}{*}{ NO } & \multirow[t]{2}{*}{ Code } & \multicolumn{6}{|c|}{ Year } & \multirow{2}{*}{$\begin{array}{r}\text { LQ } \\
\text { Average }\end{array}$} \\
\hline & & 2011 & 2012 & 2013 & 2014 & 2015 & 2016 & \\
\hline 1 & 10 & 1.57 & 1.72 & 1.62 & 3.47 & 4.08 & 3.59 & 2.67 \\
\hline 2 & 11 & 0.52 & 0.75 & 0.90 & 0.38 & 0.55 & 0.58 & 0.61 \\
\hline 3 & 12 & 18.23 & 22.21 & 23.61 & 9.17 & 15.97 & 16.96 & 17.69 \\
\hline 4 & 13 & 1.76 & 1.88 & 2.28 & 1.74 & 2.03 & 2.02 & 1.95 \\
\hline 5 & 14 & 0.40 & 0.47 & 0.45 & 0.37 & 0.29 & 0.26 & 0.37 \\
\hline 6 & 15 & 0.00 & 0.00 & 0.00 & 0.00 & 0.00 & 0.00 & 0.00 \\
\hline 7 & 16 & 1.88 & 2.44 & 2.62 & 0.99 & 1.58 & 1.70 & 1.87 \\
\hline 8 & 17 & 14.02 & 17.95 & 18.76 & 8.18 & 13.49 & 7.03 & 13.24 \\
\hline 9 & 18 & 0.01 & 0.02 & 0.02 & 0.01 & 0.00 & 0.01 & 0.01 \\
\hline 10 & 19 & 0.00 & 0.00 & 0.00 & 0.00 & 0.00 & 1.55 & 0.26 \\
\hline 11 & 20 & 1.41 & 1.16 & 1.22 & 0.54 & 0.79 & 0.88 & 1.00 \\
\hline 12 & 21 & 0.00 & 0.00 & 0.00 & 0.00 & 0.00 & 0.00 & 0.00 \\
\hline 13 & 22 & 0.39 & 0.50 & 0.54 & 0.23 & 0.01 & 0.01 & 0.28 \\
\hline 14 & 23 & 2.27 & 2.50 & 0.92 & 0.44 & 1.58 & 0.41 & 1.35 \\
\hline 15 & 24 & 0.00 & 0.00 & 0.00 & 0.00 & 0.00 & 0.00 & 0.00 \\
\hline 16 & 25 & 0.12 & 0.14 & 0.15 & 0.09 & 0.16 & 0.15 & 0.13 \\
\hline 17 & 26 & 0.05 & 0.07 & 0.07 & 0.03 & 0.05 & 0.05 & 0.05 \\
\hline 18 & 27 & 0.00 & 0.00 & 0.00 & 0.00 & 0.00 & 0.00 & 0.00 \\
\hline 19 & 28 & 1.14 & 2.03 & 2.17 & 0.03 & 0.04 & 0.04 & 0.91 \\
\hline 20 & 29 & 2.20 & 2.79 & 2.63 & 1.02 & 1.58 & 1.62 & 1.97 \\
\hline 21 & 30 & 0.76 & 0.47 & 0.45 & 0.19 & 0.26 & 0.29 & 0.41 \\
\hline 22 & 31 & 0.36 & 0.54 & 0.57 & 0.24 & 0.37 & 0.39 & 0.41 \\
\hline 23 & 32 & 0.99 & 0.38 & 0.38 & 0.17 & 0.23 & 0.55 & 0.45 \\
\hline 24 & 33 & 0.34 & 0.39 & 0.40 & 0.14 & 0.20 & 0.24 & 0.29 \\
\hline
\end{tabular}

Source: Department of Industry and Labor Lima Puluh Kota Regency and West Sumatra Provinces, data is processed by researchers, 2019.

The results of the analysis with the shift share method, shown in Table 3. In Table 3 also displayed the results of LQ method analysis, so that it can be seen the comparison 
of the results of the analysis. There are 6 types of industries with positive differential shift values, namely: (1) food, (2) drinks, (3) textiles, (4) metal goods not machinery and equipment, (5) computer, electronic and optical computer industries, (6) furniture. By considering the differential shift value in shift share analysis, it can be analyzed whether the competitiveness of an industry. The value of a positive differential shift can be categorized as an industry that has a competitive advantage. While twenty other industries do not have competitive advantages. In Table 3, It is known that the food industry and the textile industry are industries that have comparative and competitive advantages. The results of the analysis show that these two industries have the potential to become the leading SMIs of Lima Puluh Kota Regency. This industry which has high competitiveness which will be able to accelerate to increase the gross regional domestic product.

Table 3. Comparison LQ and shift share analysis of SMIs at Lima Puluh Kota Regency in 2011-2016

\begin{tabular}{|c|c|c|c|c|}
\hline NO & Code & Industry & $\begin{array}{c}\text { LQ } \\
\text { Average }\end{array}$ & $\begin{array}{l}\text { Differential Shift } \\
\text { (Rp.000) }\end{array}$ \\
\hline 1 & 10 & Foods & 2.67 & $307,410,825$ \\
\hline 2 & 11 & Drinks & 0.61 & 419,015 \\
\hline 3 & 12 & Tobacco Manufacturing & 17.69 & $(41,699)$ \\
\hline 4 & 13 & Textile & 1.95 & $6,494,081$ \\
\hline 5 & 14 & Garment & 0.37 & $(3,382,897)$ \\
\hline 6 & 15 & Leather, Leather Goods and Footwear & 0.00 & \\
\hline 7 & 16 & $\begin{array}{l}\text { Wood, Wood Products (excluding furniture) and Cork, } \\
\text { Woven Goods from Bamboo, Rattan and the like. }\end{array}$ & 1.87 & $(2,981,548)$ \\
\hline 8 & 17 & Paper and Paper Products & 13.24 & $(264,213)$ \\
\hline 9 & 18 & Printing and Reproduction of Recording Media & 0.01 & $(1,260,815)$ \\
\hline 10 & 19 & Coal and Petroleum & 0.26 & - \\
\hline 11 & 20 & Chemicals and items from chemicals & 1.00 & $(63,706,354)$ \\
\hline 12 & 21 & Pharmacy, Chemical and Traditional Medicine Products & 0.00 & - \\
\hline 13 & 22 & Rubber, Rubber Products and Plastic Items & 0.28 & $(41,957,472)$ \\
\hline 14 & 23 & Non-Metallic Mining Goods & 1.35 & $(92,408,578)$ \\
\hline 15 & 24 & Base metal & 0.00 & - \\
\hline 16 & 25 & Metal Goods Not Machines and Equipment & 0.13 & 374,393 \\
\hline 17 & 26 & Computers, Electronics and Optics & 0.05 & 3,313 \\
\hline 18 & 27 & Electrical equipment & 0.00 & - \\
\hline 19 & 28 & Machinery and Equipment & 0.91 & $(3,992,514)$ \\
\hline 20 & 29 & Motorized Vehicles, Trailers and Semi Trailers & 1.97 & $(1,489,571)$ \\
\hline 21 & 30 & Other Transport Equipment & 0.41 & $(1,226,889)$ \\
\hline 22 & 31 & Furniture & 0.41 & $2,328,606$ \\
\hline 23 & 32 & Other Manufacturing & 0.45 & $(831,148)$ \\
\hline 24 & 33 & Machine Repair and Installation Services & 0.29 & $(579,894)$ \\
\hline
\end{tabular}

The results of processing using SMIs data based on five digits Indonesian Standard Business Classifications (by commodity) can be seen in Table 4 . There are 68 SMIs as a whole, 52 SMIs groups have comparative and or competitive advantages, 16 SMIs do not have comparative and/or competitive advantages. There are 45 SMIs with an average value of LQ>1, 14 SMIs with positive differential shift (Ds) values, and 8 SMIs with an average LQ> 1 and positive Ds. SMis with the highest LQ average is, other water biota fumigation industry $(19,18)$, basic organic chemical industry for dyestuff and pigment raw material $(19,18)$, ready-made mortar or concrete industry $(18,95)$, industry clove cigarettes $(18,39)$, and the tobacco drying and processing industry $(17,18)$. 
Table 4. Leading SMIs of Lima Puluh Kota Regency

\begin{tabular}{|c|c|c|c|c|}
\hline No & Code & Industry comodity & $\begin{array}{l}\text { Average } \\
\text { LQ }\end{array}$ & $\begin{array}{r}\text { Differential } \\
\text { Shift }\end{array}$ \\
\hline 1 & 10292 & Other Water Biota Fumigation Industry & 19.18 & 0.00 \\
\hline 2 & 20116 & $\begin{array}{l}\text { Basic Organic Chemical for Raw Materials for Dyes and Pigments, } \\
\text { Dyes and Pigments Industry }\end{array}$ & 19.18 & 0.00 \\
\hline 3 & 23957 & Ready-to-use Mortar or Concrete Industry & 18.95 & $(35,500.00)$ \\
\hline 4 & 12011 & Cigarette Industry & 18.39 & 0.00 \\
\hline 5 & 12091 & Tobacco Drying and Manufacturing & 17.18 & $(41,479.07)$ \\
\hline 6 & 10779 & Other Cooking Products Industry & 16.92 & $(338,463.76)$ \\
\hline 7 & 23919 & Fireproof Goods from Clay / Ceramics, Others Industry & 16.53 & $(15,380.37)$ \\
\hline 8 & 16294 & Rattan and Bamboo Wood Kitchen Tools Industry & 15.04 & $(112,000.00)$ \\
\hline 9 & 20121 & Natural / Non Synthetic Fertilizers Primary Macro Nutrients Industry & 14.46 & $(1,202,181.11)$ \\
\hline 10 & 17099 & Other industrial paper and board items which are not classified & 13.47 & $(279,206.62)$ \\
\hline 11 & 16230 & Wooden Containers & 13.32 & $79,225.08$ \\
\hline 12 & 14112 & Leather Clothing & 12.99 & $81,061.83$ \\
\hline 13 & 30912 & Components and Supplies of Two and Three Wheeled Motorcycle & 12.53 & $597,938.36$ \\
\hline 14 & 32111 & Jewel Industry & 12.03 & $(2,181,650.00)$ \\
\hline 15 & 16293 & Wood Carving Craft Not Mebeller & 11.76 & $(1,737,751.10)$ \\
\hline 16 & 22123 & Crumb Rubber & 11.63 & 0.00 \\
\hline 17 & 26210 & Computer and / or computer assembly & 11.56 & $(7,200,000.00)$ \\
\hline 18 & 23943 & Gypsum & 9.95 & $52,037.23$ \\
\hline 19 & 10611 & Grain Cleaning and Grains & 9.94 & $(19,228,729.45)$ \\
\hline 20 & 13112 & Yarn Spinning & 8.73 & $(9,595.68)$ \\
\hline 21 & 23963 & Stone Goods for Household and Display Purposes & 7.87 & $151,768.54$ \\
\hline 22 & 10399 & Other Manufacturing and Preservation of Fruits and Vegetables & 7.66 & 0.00 \\
\hline 23 & 10520 & Liquid Milk and Milk Powder Manufacturing & 7.43 & 0.00 \\
\hline 24 & 13121 & Weaving Industry (Not Weaving Burlap Sacks and Other Sacks) & 5.94 & $(2,176,900.01)$ \\
\hline 25 & 10722 & Red Sugar Indu & 5.61 & $(375,809.56)$ \\
\hline 26 & 10801 & ation Industry & 5.58 & $(9,574,977.40)$ \\
\hline 27 & 16221 & Building Goods From Wood & 5.27 & $(52,347,425.26)$ \\
\hline 28 & 23942 & Limestone & 5.09 & $(7,657,463.58)$ \\
\hline 29 & 32909 & Other Manufacturing Not Classified Elsewhere & 4.49 & $(1,604,977.04)$ \\
\hline 30 & 16292 & Woven Industry From Non-Rattan and Bamboo Plants & 3.62 & $(371,223.32)$ \\
\hline 31 & 13942 & Rope Industry & 3.33 & $(3,768.44)$ \\
\hline 32 & 10761 & Coffee and Tea Manufacturing & 3.33 & $(8,905,998.07)$ \\
\hline 33 & 10391 & Soybean Tempe & 3.09 & $(21,278,336.85)$ \\
\hline 34 & 10740 & Macaroni, Noodle and Similar Products & 2.79 & $(705,754.31)$ \\
\hline 35 & 10794 & Crackers, Chips, Peyek and the like & 2.42 & $(10,468,582.14)$ \\
\hline 36 & 10618 & $\begin{array}{l}\text { Manufacture Of Various Kinds Of Flour From Grains, Grains, Beans, } \\
\text { Tubers, And The Like. }\end{array}$ & 2.40 & $(89,319.58)$ \\
\hline 37 & 11040 & Soft Drinks & 2.33 & $904,468.17$ \\
\hline 38 & 23932 & Manufacture of household appliances from clay / ceramics & 2.14 & $(2,547.63)$ \\
\hline 39 & 29200 & Four Wheel Or More Motorized Vehicle Body & 2.09 & $(1,315,573.59)$ \\
\hline 40 & 13912 & Embroidery & 2.04 & $10,040,369.99$ \\
\hline 41 & 10710 & Bread and Cake Products Industry & 1.55 & $(3,750,282.04)$ \\
\hline 42 & 19292 & Coal Briquette Industry & 1.46 & 0.00 \\
\hline 43 & 23921 & Manufacture of Bricks From Clay / Ceram & 1.40 & $(94,404,710.41)$ \\
\hline 44 & 28210 & Agriculture and Forestry Machinery Industry & 1.33 & $(6,156,951.20)$ \\
\hline 45 & 10422 & Coconut Oil Industry & 1.17 & $71,870.15$ \\
\hline 46 & 25920 & $\begin{array}{l}\text { Industrial Services For Various Special Works On Metals And Goods } \\
\text { From Metals }\end{array}$ & 0.80 & $181,956.18$ \\
\hline 47 & 16299 & Manufacture Of Wood, Rattan, Cork, And Other Non-Certified Products & 0.70 & $53,572.38$ \\
\hline 48 & 25931 & Industrial Cutlery and Hand Tools for Agriculture & 0.53 & $301,223.91$ \\
\hline 49 & 31001 & Wood Furniture Industry & 0.42 & $2,329,828.22$ \\
\hline 50 & 11050 & Industry of Drinking Water and Mineral Water & 0.33 & $671,537.34$ \\
\hline 51 & 22299 & Other Plastic Goods Industry Not Classified Elsewhere & 0.10 & $31,113.77$ \\
\hline 52 & 25111 & $\begin{array}{l}\text { Manufacture of Non-Aluminum Metal Products Ready to Install for } \\
\text { Buildings }\end{array}$ & 0.04 & $61,017.13$ \\
\hline
\end{tabular}

Source: Department of Industry and Labor Lima Puluh Kota Regency and West Sumatra Provinces, data is processed by researchers, 2019. 
The results of the LQ analysis show that $66 \%$ of the commodities SMIs in Lima Puluh Kota Regency have comparative advantages. The results of shift-share analysis, $21 \%$ of SMIs have a competitive advantage. So that overall $10 \%$ of SMIs have a comparative and competitive advantage. This is an indication that the industrial sector, especially SMIs, has the potential to develop more optimally. Industrial development is still at an early stage, where existing industrial commodities are in the form of one-step processed products after raw materials. To develop this industry, downstream industries are needed. Industries that are found to have advantages and have the potential to become large industries, must be made mapping of product development.

The basic organic chemical industry for raw materials for dyes and pigments with gambier commodities is a potential SMIs of Lima Puluh Kota Regency with the highest average LQ, but from data processing with the shift-share method has a differential shift value of zero (0). Based on data from the potential of the SMIs of West Sumatra Province, gambier producers in West Sumatra are only found in Lima Puluh Kota Regency. It can be concluded that the commodity gambier has an absolute advantage. The shift-share method cannot identify this through the differential shift value. Because the value of the differential shift is the difference in the growth of Regency commodities with the Province. If the growth is the same, then the differential shift value becomes zero (0). If the growth of SMI in the district is higher, then the differential shift value will be positive. And if the SMI growth in the Regency is lower, the differential shift value becomes negative.

Commodity from industrial organic raw material for raw materials for dyes and pigments is gambier. Gambier is in the district Kapur IX, Pangkalan Koto Baru, Lareh Sago Halaban, Harau, Mungka and Bukit Barisan. Gambier is the main export commodity of Lima Puluh Kota Regency, but still an upstream industry with very simple technology. The average number of business units in 2011-2016 is 4.298 business units, in the small industry category. The number of workers absorbed by the 2011-2016 average is 12,766 people. Production of gambier Lima Puluh Kota Regency is the largest in West Sumatra and Indonesia, with the number of production in 2016 is 8,096 tons. The commodity of gambier manufacturing industry is gambir mortar which is the raw material for dyes. The development of processed products from other gambir is gambir leaf tea. The development of gambir industry is very necessary, because this industry has the potential to become a big industry. Gambir manufacturing products can still be developed further through product development research. So that the added value of gambir products can increase to higher.

The production center of the embroidery industry is in the district Payakumbuh and Mungka. The commodity is embroidery material/fabric for clothing, headscarves and mukena. The average number of business units in 2011-2016 is 138 units. The number of workers absorbed 2,787 people. Embroidery industry in the form of small industries and medium industries. Other industries which have comparative and competitive advantages in the District of Lima Puluh Kota are spread over 13 districts, namely Harau, Payakumbuh, Situjuah Limo Nagari, Lareh Sago Halaban, Luak, Akabiluru, Guguak, Mungka, Suliki, Gunuang Omeh, Bukit Barisan, Pangkalan Koto Baru and Kapur IX. The number of business units of these industries is a small average of 20 business units with employment of 5-150 people. We can conclude that SMIs that has advantages in Lima Puluh Kota Regency have characteristics, are labor intensive, workforce with simple expertise, use simple technology, limited capital and use raw materials sourced from agricultural, plantation, forestry, mining products. Industries that 
are developing are directed towards the agro industry. This is in accordance with the opinion of Tarigan (2009), comparative advantage can be owned by an area including due to natural factors and also the skills of the people who have been entrenched.

Determination of SMIs that will become a leading industries by choosing SMIs that has a comparative advantage as well as a competitive advantage. Other SMIs that only have comparative or competitive advantages, become potential IKMs which are the next priority. Based on analysis of LQ and shift-share, industries which are priorities in the development of SMIs in Lima Puluh Kota Regency are as follows:

1. Basic Organic Chemicals for Raw Materials for Dyes and Pigments Industry.

2. Embroidery Industry.

3. Wooden Containers Industry.

4. Leather Clothing Industry

5. Stone Goods for Household and Display Purposes Industry.

6. Gypsum Industry.

7. Components and Supplies of Two and Three Wheeled Motorcycle Industry.

8. Soft drink Industry.

9. Coconut Crude Oil Industry.

The leading SMIs from the results of LQ analysis and shift share can be used as a reference in determining priority SMIs in regional industrial planning policy making. This policy in addition to considering competitive and comparative advantages, also considers other aspects such as the sustainability of the availability of raw materials and environmental aspects.

\section{CONCLUSIONS AND RECOMMENDATIONS}

\section{Conclusions}

From LQ and shift share analysis, we have found there are 66\% SMIs that have comparative advantages, $21 \%$ SMIs have competitive advantages and 10\% SMIs have both. SMIs that have a comparative as well as competitive advantages are basic organic chemical industries for raw materials for dyes and pigments, embroidery industry, wood container industry, garment industry of leather, industrial stone goods for household use and displays, cast industry, component industry and two and three-wheeled motorcycle equipment, soft drink industry and coconut oil-eating industry.

\section{Recommendations}

Based on the results of this study, it is expected that the Lima Puluh Kota Regency as policy makers, to prioritize the development of SMIs that have comparative as well as competitive advantages by considering aspects of employment, availability of renewable raw materials and environmental aspects. To develop SMIs, downstreaming industries are needed because existing industrial commodities are in the form of onestep processed products after raw materials. Industries that are found to have advantages and have the potential to become large industries, must be made mapping of product development. Then, other SMIs that do not have comparative or competitive advantages remain driven through consistent policies and guidance, so that later they can grow into industries that have a comparative and competitive advantage.

\section{REFERENCES}

Adrimas. (2008). Pembangunan Industri di Sumatera Barat: Pertumbuhan, Permasalahan dan Kebijakan. Jurnal Manajemen dan Pembangunan, 7(2), 
2374-2385.

Badan Pusat Statistik. (2009). Peraturan Kepala Badan Pusat Statistik Nomor 59 Tahun 2009 Tentang Klasifikasi Baku Lapangan Usaha Indonesia. Jakarta: Badan Pusat Statistik.

Badan Pusat Statistik Kabupaten Lima Puluh Kota. (2016). PDRB Kabupaten Lima Puluh Kota Menurut Lapangan Usaha 2011-2015. Sarilamak: Badan Pusat Statistik (BPS) Kabupaten Lima Puluh Kota.

Badan Pusat Statistik Kabupaten Lima Puluh Kota. (2017). PDRB Kabupaten Lima Puluh Kota Menurut Lapangan Usaha 2012-2016. Sarilamak: Badan Pusat Statistik Kabupaten Lima Puluh Kota.

Bao-jin, X., Xing-peng, C., \& Li-na, W. (2010). Industrial Structure Evolution and Economic Growth in Dingxi City based on Shift-share Method and Location Quotient Analysis. Asian Agriculture Research, 2(12), 61-64.

Irmawati, S. (2015). Analisis Industri Unggulan di Provinsi Jawa Tengah. JEJAK Journal of Economics and Policy, 8(2), 224-237.

Kementrian Perindustrian. (2014). Undang-undang Nomor 3 Tahun 2014 tentang Perindustrian. Jakarta: Kementrian Perindustrian.

Permana, A. I., Marimin, \& Suprayitno, G. (2015). Model Konseptual Strategi Pengembangan Industri Kecil Menengah Berbasis Sumber Daya (Studi Kasus Pengembangan IKM di Pangalengan). Jurnal Teknologi Industri Pertanian, 25(1), 14-20.

Pinem, D. E. (2016). Menemukan Strategi Pengembangan Kawasan Industri Melalui Analisis Sektor Unggulan Kota Binjai. Jurnal Wilayah dan Lingkungan, 4(1), 45-64.

Pradigda, E. A. (2016). Strategi Perencanaan Pembangunan Industri Berbasis Produk Unggulan Daerh, Studi pada Dinas Perindustrian dan Perdagangan Kabupaten Blitar. Jurnal Paradigma, 5(3), 112-131.

Sjafrizal. (2014). Ekonomi Wilayah dan Perkotaan. Jakarta: Erlangga.

Sjafrizal. (2016). Perencanaan Pembangunan Daerah Dalam Era Otonomi. Jakarta: PT. RajaGrafindo Persada.

Tan, S. (2010). Perencanaan Pembangunan (Teori dan Implementasi pada Pembangunan Daerah) (1st ed.). Jambi: Fakultas Ekonomi Universitas Jambi.

Tarigan, R. (2009). Ekonomi Regional Teori dan Aplikasi (5th ed.). Jakarta: PT. Bumi Aksara. 